Marquette University

e-Publications@Marquette

Biomedical Engineering Faculty Research and

Publications

Engineering, College of

$11-1-2002$

\title{
A Rehabilitation Engineering Course for Biomedical Engineers
}

M. Barbara Silver-Thorn

Marquette University, barbara.silver-thorn@marquette.edu

Accepted version. IEEE Transactions on Education, Vol. 45, No. 4 (November 2002): 299-306. DOI. (C) 2002 Institute of Electrical and Electronics Engineers (IEEE), Used with permission. 


\title{
A Rehabilitation Engineering Course For Biomedical Engineers
}

\author{
M.B. Silver-Thorn \\ Department of Biomedical Engineering, Marquette University, Milwaukee, WI
}

\begin{abstract}
This paper describes an upper division elective course in rehabilitation engineering that addresses prosthetics and orthotics, wheelchair design, seating and positioning, and automobile modifications for individuals with disabilities. Faculty lectures are enhanced by guest lectures and class field trips. Guest lecturers include a prosthetist and a lower extremity amputee client, an engineer/prosthetist specializing in the upper extremity, and a rehabilitation engineer. The lower extremity prosthetist and his client present a case study for prosthetic prescription, fabrication, fitting, alignment, and evaluation. The engineer/prosthetist contrasts body-powered versus externally powered upper extremity prostheses and associated design, fitting, and functional considerations; he also discusses myoelectric signal conditioning, signal processing, and associated control strategies for upper extremity prosthetic control. Finally, the rehabilitation engineer presents case studies related to assessment and prescription of mobility aids, environmental control systems, and children's toys. The course also includes visits to a local prosthetic and orthotic facility to observe typical fabrication, fitting, and alignment procedures and a driver rehabilitation program for exposure to driver assessment, training, and common vehicle modifications. These applications of biomedical engineering to persons with disabilities have been well received by the students and have furthered interdisciplinary design and research projects.
\end{abstract}


NOT THE PUBLISHED VERSION; this is the author's final, peer-reviewed manuscript. The published version may be accessed by following the link in the citation at the bottom of the page.

\section{SECTION I.}

\section{Introduction}

The Biomedical Engineering program at Marquette University, Milwaukee, WI, was first established as a degree-granting program within the Electrical Engineering Department in 1959. Since that time, the bioelectronics-based program has awarded baccalaureate and graduate degrees (M.S. and Ph.D.). In 1990, the biomechanics major was initiated, and most recently (1999), a biocomputing major was introduced. The curriculum for all students majoring in biomedical engineering includes two technical electives, typically taken during the senior year. Many technical electives can also be taken for graduate credit with additional responsibilities.

Rehabilitation engineering has been defined as "the branch of biomedical engineering that is concerned with the application of science and technology to improve the quality of life of individuals with disabilities". ${ }^{1}$ As such, rehabilitation engineering encompasses prosthetics and orthotics, wheelchair and seating systems, alternative and augmentative communication, environmental control systems, and sensory aids. These fields rely heavily on custom prescription and design, technology, and technology transfer and therefore present numerous opportunities and challenges for biomedical engineers.

Inclusion of rehabilitation engineering courses and/or design projects is, therefore, important in biomedical engineering, and many biomedical engineering departments and programs offer courses in rehabilitation at the graduate and/or undergraduate level (Table I). These courses focus on prosthetics and orthotics, assistive technology, ergonomics, or rehabilitation engineering design projects. In contrast, the course described in this paper emphasizes clinical problem solving (rather than design projects) and encompasses a broad range of topics. This course is interdisciplinary, including guest lecturers and hands-on field trips, and, unlike many of the courses summarized in Table I, is available to both undergraduate and graduate students in biomedical engineering. 
TABLE I Summary of Rehabilitation Engineering Courses Offered byBiomedical EngineeringPrograms/Departments

\begin{tabular}{|c|c|c|}
\hline Callege / Unwersity & Course Title & Topics \\
\hline $\begin{array}{l}\text { Arizona State } \\
\text { University }\end{array}$ & BME 532: Prosthetic \& Rehab Eng & $\begin{array}{l}\text { Design and control strategies for } \\
\text { medical devices in rehab eng }\end{array}$ \\
\hline Catholic University & $\begin{array}{l}\text { BE 524: Principles of Prosthetics \& Orthotics } \\
\text { BE 528: Rehab Eng Design }\end{array}$ & $\begin{array}{l}\text { Theory and practice of } \\
\text { prosthetics \& orthotics } \\
\text { Designing aids for persons with } \\
\text { disabilities }\end{array}$ \\
\hline $\begin{array}{l}\text { Louisiana Tech } \\
\text { Universily }\end{array}$ & $\begin{array}{l}\text { GralEN 562/3: Rehab Engineering and Assistive } \\
\text { Technology i \& II }\end{array}$ & $\begin{array}{l}\text { Activities of daily living. } \\
\text { alternative augmentative } \\
\text { communication, computer } \\
\text { access, assistive technology }\end{array}$ \\
\hline $\begin{array}{l}\text { Northwestern } \\
\text { University }\end{array}$ & $\begin{array}{l}\text { BME 365: Control of Human Limbs and their } \\
\text { Artificial Replacements }\end{array}$ & $\begin{array}{l}\text { Human movement. musculoskeletal } \\
\text { anatomy, comparative anatomy, } \\
\text { engineering design of artificial limbs }\end{array}$ \\
\hline University of Akron & "Fe्सME 655: Rehab Eng & $\begin{array}{l}\text { Devices for rehab, sensory aids, } \\
\text { communication aids, } \\
\text { assessment techniques, } \\
\text { prosthetics \& orthotics, bedsore } \\
\text { biomechanics, functional } \\
\text { electrical stimulation }\end{array}$ \\
\hline $\begin{array}{l}\text { University of } \\
\text { Michigan }\end{array}$ & BME 530: Rehab Eng and Assistive Technology & $\begin{array}{l}\text { Wheeled mobility, seating \& } \\
\text { positioning. environmental } \\
\text { control, augmentative } \\
\text { communication, sensory aids, } \\
\text { work site modification, adaptive } \\
\text { driving aids }\end{array}$ \\
\hline $\begin{array}{l}\text { University of } \\
\text { Pittsburgh }\end{array}$ & $\begin{array}{l}\text { "DioE 2709: Rehab Biomechanics } \\
\text { School of Health \& Rehab Sciences: numerous } \\
\text { courses }\end{array}$ & $\begin{array}{l}\text { Fundamentals of biomechanics } \\
\text { applied to rehabilitation }\end{array}$ \\
\hline $\begin{array}{l}\text { University of Southem } \\
\text { California }\end{array}$ & BME 414 (BME 499): Rehab Engineering & $\begin{array}{l}\text { Orthotics, limb prosthetics, } \\
\text { devices aiding mobility, seating } \\
\text { aids, workplace/home } \\
\text { modifications, functional } \\
\text { electrical stimulation, computer } \\
\text { access, altemative augmentative } \\
\text { communication, technology } \\
\text { transfer }\end{array}$ \\
\hline $\begin{array}{l}\text { University of } \\
\text { Tennessee, Memphis }\end{array}$ & $\begin{array}{l}\text { BiOM 840: Special Topics - Biomechanics } \\
\text { and Rehab Eng }\end{array}$ & \\
\hline $\begin{array}{l}\text { Virginia } \\
\text { Commonwealth } \\
\text { University }\end{array}$ & EGTB 420: Rehab Engineering & $\begin{array}{l}\text { Rehab eng: interaction of } \\
\text { biomedical engineering with } \\
\text { health care delivery; cerebral } \\
\text { palsy muscular dystrophy, spinal } \\
\text { cord injury }\end{array}$ \\
\hline $\begin{array}{l}\text { Wright State } \\
\text { University }\end{array}$ & 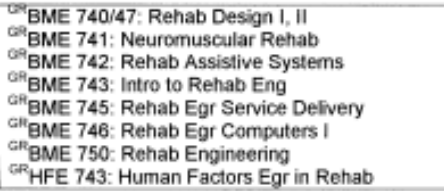 & \\
\hline
\end{tabular}

\section{SECTION II.}

\section{Course Structure}

This technical elective course is titled Rehabilitation Engineering-Prosthetics, Orthotics, Seating and Positioning. The prerequisites are minimal and include knowledge of statics and dynamics. Enrollment typically includes biomechanics (65\%) and bioelectronics undergraduates (10\%), ${ }^{1}$ as well as biomedical engineering graduate students (25\%). Offered nearly every spring semester since 1994, enrollment has ranged from 8 to 26 students. (As a reference, there are approximately 250 undergraduate and 55 graduate students in Biomedical Engineering at Marquette University.) 
The goal of this course is to apply biomedical engineering principles to the design and development of artificial limbs, orthotic devices, and seating systems. Specific course objectives are:

1. to familiarize students with the musculoskeletal anatomy of the upper and lower extremities;

2. to familiarize students with muscle mechanics and the electromyogram;

3. to familiarize students with human locomotion in terms of terminology and characterization of normal versus pathologic function;

4. to familiarize students with biologic soft tissue and interface mechanics related to seating, positioning, prostheses, and load transfer;

5. to familiarize students with amputation surgery techniques and factors influencing amputation level selection;

6. to familiarize students with lower and upper extremity prosthetic components and factors influencing prosthetic prescription;

7. to familiarize students with lower and upper extremity orthotic components and factors influencing orthotic prescription;

8. to familiarize students with various methods of prosthetic and orthotic control and power;

9. to familiarize students with biomechanical design principles related to seating and stabilization;

10. to familiarize students with commercial products, design principles, and factors influencing prescription and assessment for both wheelchairs and automotive aids.

Details regarding how this course addresses the program educational objectives and outcomes are presented in Section VII. This course has been classified as $50 \%$ engineering science, 16\% engineering design, and 34\% basic science (anatomy and physiology).

The course includes two 75-minute lectures per week (30 lectures per semester). Lecture topics include: 1) background material (e.g., medical terminology, musculoskeletal anatomy, muscle mechanics, balance and gait, soft tissue mechanics, and amputation surgery), 2) lower extremity prosthetics and orthotics, 3) upper extremity prosthetics and orthotics, 4) seating and positioning, 5) wheelchair design, and 6) assistive devices. These topics are further described in Fig. 1. 
NOT THE PUBLISHED VERSION; this is the author's final, peer-reviewed manuscript. The published version may be accessed by following the link in the citation at the bottom of the page.

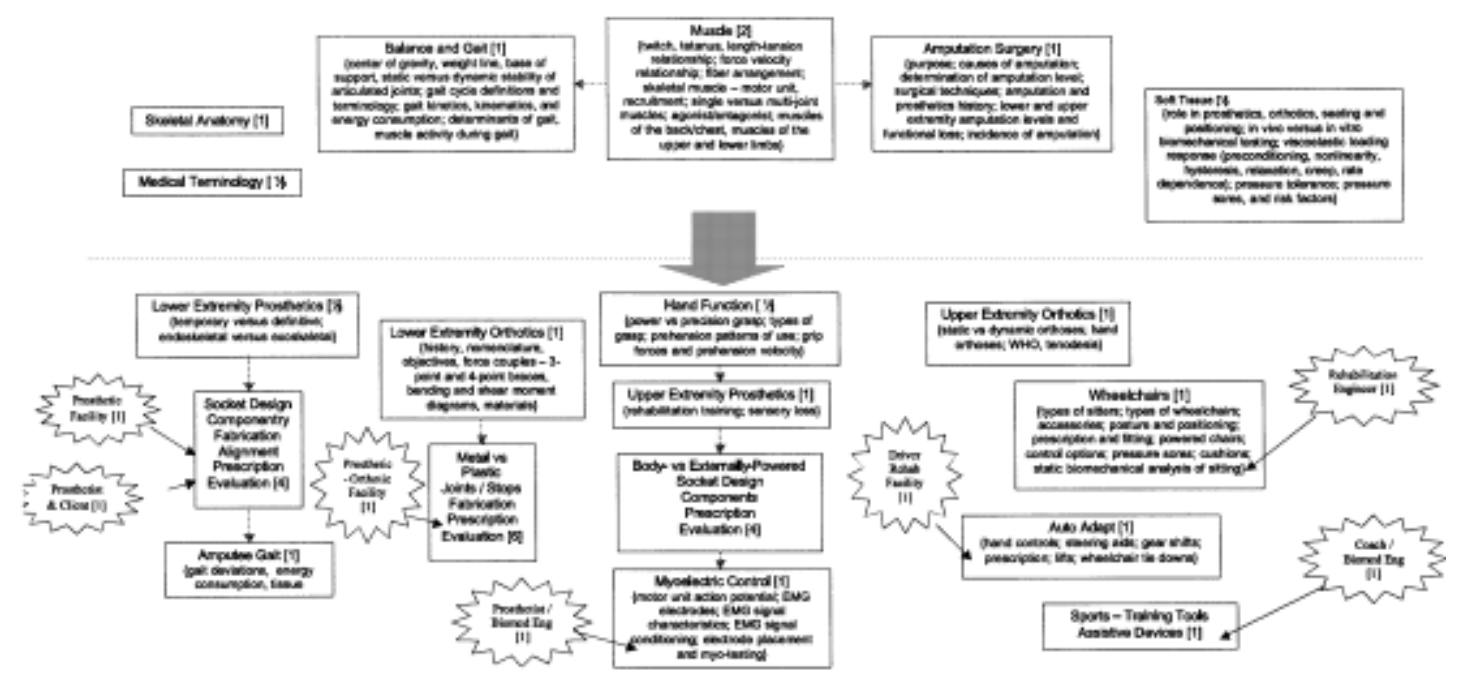

Fig. 1. Course organization. The top blocks refer to introductory material covered during weeks 1-3. The blocks on the lower half of the figure (flow is from top to bottom, left to right) correspond to weeks 415. The number of lectures devoted to a specific topic or series of topics is indicated in brackets. All guest lectures and field trips are contained in bubbles; they are scheduled to coincide with the specific lecture block to which they are linked.

Several hundred pages of lecture notes based on more than 25 references $^{2-}$ $3,4,5,6,7,8,9,10,11,12,13,14,15,16,17,18,19,20,21,22,23,24,25,26,27$ were compiled specifically for this course. The respective texts, as well as the lecture notes, are placed on two-hour reserve at the library. This material was available to enrolled students via the Internet using Blackboard ${ }^{2}$ in January 2002.

A unique aspect of the course is the "special events," which include guest lectures and class field trips. Guest lectures are typically scheduled during class, but the class period is extended to two hours. Field trips may or may not be conducted during the scheduled class time. The class votes on alternative days and times (including Saturdays), and the trip is scheduled so that as many students as possible can attend.

\section{SECTION III.}

\section{Guest Lectures and Lecturers}

Many of the guest lecturers have been involved with the course since 1994. These individuals, their areas of expertise, and their respective lecture topics are highlighted in this section. The timeliness of these guest lectures with respect to the course is illustrated in Fig. 1. 
NOT THE PUBLISHED VERSION; this is the author's final, peer-reviewed manuscript. The published version may be accessed by following the link in the citation at the bottom of the page.

\section{Certified Prosthetist ${ }^{3}$}

Although a prosthetist has experience in both lower and upper extremity prosthetic fitting, the in-class guest lecture addresses lower extremity prosthetic prescription. This guest lecture follows class lectures on lower extremity prosthetic socket design, prosthetic feet and knee units, prosthetic alignment, and prosthetic prescription and evaluation. An amputee client, typically an individual with transtibial amputation, accompanies the prosthetist on this campus visit. The prosthetist directs the students in obtaining a relevant medical history and helps them evaluate prosthetic components and socket design issues necessary to write a prosthetic prescription. The client addresses student questions regarding his/her amputation, rehabilitation, and difficulties encountered.

\section{Prosthetist/Biomedical Engineer ${ }^{4}$}

This guest lecture is scheduled after the students have reviewed upper extremity anatomy, hand function, electromyography, upper extremity prosthetic socket design, upper extremity prosthetic components (e.g., terminal devices and wrist/elbow/shoulder units), upper extremity prosthetic control options (body-powered versus externally powered), and prosthetic prescription and assessment. The lecture includes a review of upper extremity prosthetics and comparison of body-powered versus externally powered prostheses. The guest lecturer's engineering training and clinical experience facilitates thorough discussion of myoelectric signal acquisition, processing, and limitations related to upper extremity prosthetic control. This lecture is supported by demonstration of numerous upper extremity prosthetic devices (e.g., hands or hooks) and videos of upper extremity prosthetic users illustrating prosthetic fitting, prosthetic donning and doffing, and the performance of many activities of daily living.

\section{Rehabilitation/Biomedical Engineer ${ }^{5}$}

This guest lecture is scheduled near the end of the semester and follows lectures on seating and positioning, wheelchair design (including control options), and prescription. The lecture includes discussion of clinical issues related to seating and positioning, contour fitting and fabrication, assessment, and client training. Adaptive equipment, toys, and environmental control systems are also presented and discussed. Numerous slides and video clips of case studies involving power wheelchair and environmental control system training comprise an integral part of this lecture.

IEEE Transactions on Educaton, Vol 45, No. 4 (November 2002): 299-306. DOI. This article is ( I Institute of Electrical and Electronics Engineers (IEEE) and permission has been granted for this version to appear in e-Publications@Marquette. Institute of Electrical and Electronics Engineers (IEEE) does not grant permission for this article to be further copied/distributed or hosted elsewhere without the express permission from Institute of Electrical and Electronics Engineers (IEEE). 


\section{Coach/Biomedical Engineer ${ }^{6}$}

This lecture, which typically wraps up the class, involves discussion of disabled athletes and training programs and resources. The guest lecturer's involvement as a swim coach for U.S. swimmers at the Paralympics and World Swimming Championships provides unique perspective. This lecture includes discussion of competitions for disabled athletes (i.e., those with amputation, spinal cord injuries, and neurologic impairments), classification levels of athletes, and training programs and resources. In addition, training aids and tools and related design considerations are presented and discussed.

Several case studies and videos illustrating competition are presented; the individual's medical history and motivation regarding athletic involvement are also discussed. These athletes present new design challenges in terms of prosthetic devices, wheelchair design, and training aids that must accommodate excessive loading imposed in competition, atypical mobility needs, and the need to minimize the mass of the respective device. 
NOT THE PUBLISHED VERSION; this is the author's final, peer-reviewed manuscript. The published version may be accessed by following the link in the citation at the bottom of the page.

TABLE II Summary of Educational Objectives Addressed by This Course

\begin{tabular}{|c|c|c|}
\hline & Program Educational Objective & Rehabilitation Engineering Course \\
\hline (2) & $\begin{array}{l}\text { To offer students a broad, } \\
\text { interdisciplinary educational program } \\
\text { that combines engineering theory. } \\
\text { design, and practice with life science. }\end{array}$ & $\begin{array}{l}\text { Students use their new-found knowledge of musculoskeletal } \\
\text { anatomy in concert with their knowledge of kinetic, kinematics, } \\
\text { and biomechanics to understand human movement and issues } \\
\text { related to limb loss and functional replacement } \\
\text { needs/concerns. Student knowledge of kinetics and kinematics } \\
\text { is also used to understand issues related to postural stability } \\
\text { for wheelchair-bound individuals with compromised } \\
\text { neuromuscular control. }\end{array}$ \\
\hline (3) & $\begin{array}{l}\text { To prepare graduates with problem } \\
\text { identification and solution skills. }\end{array}$ & $\begin{array}{l}\text { Problem identification and solution in this course involve } \\
\text { clinical diagnosis and prescription. Students identify the needs } \\
\text { of various "patients" and apply their knowledge of upper and } \\
\text { lower extremity prosthetic/orthotic components to draft } \\
\text { prosthetic/orthotic prescriptions. Such exercises provide a } \\
\text { venue for students to assess functional limitations, identify } \\
\text { patient needs, and find clinical solutions using available } \\
\text { technology. }\end{array}$ \\
\hline & $\begin{array}{l}\text { To prepare graduates who are able to } \\
\text { communicate effectively in written, } \\
\text { graphical and oral forms. }\end{array}$ & $\begin{array}{l}\text { Student assessment is largely based on their written (and oral) } \\
\text { reports and their essay responses to quiz/exam queries. The } \\
\text { course therefore provides opportunities for technical, clinical } \\
\text { communication. }\end{array}$ \\
\hline (6) & $\begin{array}{l}\text { To prepare graduates for biomedical } \\
\text { employment or post-graduate training. }\end{array}$ & $\begin{array}{l}\text { Many opportunities exist for students with rehabilitation } \\
\text { engineering training/interest in post-graduate education } \\
\text { (graduate programs in blomedical engineering and physical } \\
\text { therapy, as well as physician's assistant, prosthetics/orthotics } \\
\text { certification programs and medical school). Employment } \\
\text { opportunities in clinical research (motion analysis, sensory } \\
\text { motor performance) laboratorles also exist. This clinical } \\
\text { applications course helps students assess their interest in } \\
\text { such careers and assists in their preparation. }\end{array}$ \\
\hline$\overline{(7)}$ & $\begin{array}{l}\text { To foster an appreciation for religious, } \\
\text { moral, ethical, and human values. }\end{array}$ & $\begin{array}{l}\text { As rehabilitation routinely deals with health care, cost, and } \\
\text { quality of life issues, students are exposed to ethical questions } \\
\text { facing medical providers. Case studies provided by visiting } \\
\text { lecturers provide an enlightening perspective. }\end{array}$ \\
\hline & $\begin{array}{l}\text { To foster an appreciation for life-long } \\
\text { learning. }\end{array}$ & $\begin{array}{l}\text { Prosthetics and orthotics have undergone substantial product } \\
\text { changes due to materials advances. In addition, assistive } \\
\text { technology products are continually modified to take } \\
\text { advantage of technological advances affecting user interface } \\
\text { design and information exchange. Discussion of these market } \\
\text { changes and changes in health care itself by the guest } \\
\text { lecturers emphasize the need for life-long leaming. }\end{array}$ \\
\hline & $\begin{array}{l}\text { To maintain a relevant educational } \\
\text { curriculum by interacting with industrial } \\
\text { partners. }\end{array}$ & $\begin{array}{l}\text { The field trips and guest lectures help ensure that the } \\
\text { rehabilitation issues discussed in this course remain current. } \\
\text { The individuals assisting with these visits/lectures address old } \\
\text { technology, new technology, and current market needs. }\end{array}$ \\
\hline & $\begin{array}{l}\text { To maintain a relevant educational } \\
\text { curriculum through healthcare and } \\
\text { research experiences. }\end{array}$ & $\begin{array}{l}\text { Rehabilitation engineering is "healthcare". The guest lecturers } \\
\text { and "tour guides" expose students to healthcare issues } \\
\text { affecting individuals with amputation, functional deficits, and } \\
\text { loss of mobility. These individuals anecdotally discuss product } \\
\text { advances due to recent research efforts. }\end{array}$ \\
\hline
\end{tabular}

\section{SECTION IV.}

\section{Field Trips}

Every year, the class partakes in several class excursions that provide exposure to local clinical facilities and personnel. Field trips that have been conducted on an annual basis include the following.

1. Prosthetic-Orthotic Facility ${ }^{7}$ :This facility hosts the first field trip of the course. It is scheduled after the students have learned about lower extremity amputation surgery and lower extremity prosthetic socket design and components (Fig. 1). A prosthetist $^{8}$ at these facilities presents various lower extremity prosthetic components (e.g., dynamic feet, hydraulic knees, rotators, transfemoral amputee sockets, and suspension options) and addresses student questions related to

IEEE Transactions on Educaton, Vol 45, No. 4 (November 2002): 299-306. DOI. This article is (C) Institute of Electrical and Electronics Engineers (IEEE) and permission has been granted for this version to appear in e-Publications@Marquette. Institute of Electrical and Electronics Engineers (IEEE) does not grant permission for this article to be further copied/distributed or hosted elsewhere without the express permission from Institute of Electrical and Electronics Engineers (IEEE). 
prescription, teamwork, insurance, and healthcare trends. The students then join the prosthetist as he fits and aligns a prosthesis for an individual with a transfemoral amputation.

On a second visit following class lectures on lower extremity orthotic design, the students are exposed to lower limb prosthetic and orthotic fabrication. The prosthetist and the prosthetic and orthotic technicians present various materials used in prosthetics and orthotics and demonstrate casting procedures, vacuum forming as used in prosthetics and orthotics, socket lamination, and prosthetic alignment apparatus. In addition, students are exposed to computer-aided design ${ }^{9}$ in prosthetics, including shape sensing, socket rectification using a computer, and preparation of the plaster positive.

2. Driver Assessment and Training Center ${ }^{10}$ : Students visit this facility during the last week of classes. The director of this center discusses driver assessment for individuals with disabilities, various vehicle modifications and driving aids, and driver training. The students try the driving simulator used to assess driver reflexes and cognition and view vehicles equipped with adaptive equipment (e.g., steering aids, accelerator/braking options, wheelchair lifts and tie downs). Students also meet a disabled driver (e.g., one with spinal cord injury) and view his or her custom vehicle. Students have the opportunity to ask questions regarding the individual's medical history, driving assessment and training, and vehicle modifications. 
NOT THE PUBLISHED VERSION; this is the author's final, peer-reviewed manuscript. The published version may be accessed by following the link in the citation at the bottom of the page.

TABLE III Summary of Program (ABET) Outcomes Addressed by This Course

\begin{tabular}{|c|c|}
\hline ABET Outcome & Rehabilitation Engineering Course \\
\hline $\begin{array}{l}\text { (A) Ability to apply knowledge of mathematics, } \\
\text { science and engineering }\end{array}$ & $\begin{array}{l}\text { Students use their newfound knowledge of } \\
\text { musculoskeletal anatomy in concert with their knowledge } \\
\text { of kinetic, kinematics, and biomechanics to understand } \\
\text { human movement and issues related to limb loss and } \\
\text { functional replacement needs/concerns. Student } \\
\text { knowledge of kinetics and kinematics is also used to } \\
\text { understand issues related to postural stability for } \\
\text { wheelchair-bound individuals with compromised } \\
\text { neuromuscular control. }\end{array}$ \\
\hline $\begin{array}{l}\text { (C) Ability to design a system, component, or } \\
\text { process to meet desired needs }\end{array}$ & $\begin{array}{l}\text { While students do not design specific components of } \\
\text { prostheses or orthoses, students identify the needs of } \\
\text { various "patients" and apply their knowledge of upper and } \\
\text { lower extremity prosthetic/orthotic components to draft } \\
\text { prosthetic/orthotic prescriptions. Such exercises provide } \\
\text { a venue for students to assess functional limitations, } \\
\text { identify patient needs, and find clinical solutions using } \\
\text { available technology. }\end{array}$ \\
\hline $\begin{array}{l}\text { (F) Understanding of professional and ethical } \\
\text { responsibility }\end{array}$ & $\begin{array}{l}\text { As rehabilitation routinely deals with health care, cost, } \\
\text { and quality of life issues, students are exposed to ethical } \\
\text { questions facing medical providers. Case studies } \\
\text { provided by visiting lecturers provide an enlightening } \\
\text { perspective. }\end{array}$ \\
\hline (G) Ability to communicate effectively & $\begin{array}{l}\text { Student assessment is largely based on their written (and } \\
\text { oral) reports and their essay responses to quiz/exam } \\
\text { queries. The course therefore provides opportunities for } \\
\text { technical, clinical communication. }\end{array}$ \\
\hline $\begin{array}{l}\text { (l) Recognition of the need for, and an ability to } \\
\text { engage in, life-long learning }\end{array}$ & $\begin{array}{l}\text { Prosthetics and orthotics have undergone substantial } \\
\text { product changes due to materials advances. In addition, } \\
\text { assistive technology products are continually modified to } \\
\text { take advantage of technological advances affecting user } \\
\text { interface design and information exchange. Discussion of } \\
\text { these market changes and changes in health care itself } \\
\text { by the visiting lecturers emphasize the need for life-long } \\
\text { learning. }\end{array}$ \\
\hline
\end{tabular}

\section{SECTION V.}

\section{Student Evaluation and Grading}

Grading in this class was initially based on a midterm exam (short answer, 35\%), final exam (noncumulative; short answer, 35\%), and final paper (30\%). However, student commentary indicated dissatisfaction with this format because of the bulk of material covered on each exam. As such, an alternative format with weekly quizzes (short answer, $50 \%$ ), a cumulative final exam (short answer, 25\%), and final paper (25\%) has been implemented in recent years.

IEEE Transactions on Educaton, Vol 45, No. 4 (November 2002): 299-306. DOI. This article is @ Institute of Electrical and Electronics Engineers (IEEE) and permission has been granted for this version to appear in e-Publications@Marquette. Institute of Electrical and Electronics Engineers (IEEE) does not grant permission for this article to be further copied/distributed or hosted elsewhere without the express permission from Institute of Electrical and Electronics Engineers (IEEE). 
NOT THE PUBLISHED VERSION; this is the author's final, peer-reviewed manuscript. The published version may be accessed by following the link in the citation at the bottom of the page.

TABLE IV Summary of AssessmentTools with Which This CourseIs Evaluated

\begin{tabular}{|c|c|}
\hline Assessment Tool & Rehabilitation Engineering Course Evaluation \\
\hline $\begin{array}{l}\text { (1) student performance: course, exam, written } \\
\text { report, and oral project grades }\end{array}$ & $\begin{array}{l}\text { Addresses how well students master course objectives, } \\
\text { as well as their ability to communicate effectively }\end{array}$ \\
\hline $\begin{array}{l}\text { (2) course portfolios: syllabus, sample student } \\
\text { exams, projects, field trip/guest lecture } \\
\text { evaluations }\end{array}$ & $\begin{array}{l}\text { Documents breadth of material covered, students' } \\
\text { mastery of course material, effective communication, and } \\
\text { problem solving. The course portfolios are reviewed by } \\
\text { the department undergraduate committee to evaluate the } \\
\text { course in terms of the program educational objectives } \\
\text { and outcomes. }\end{array}$ \\
\hline $\begin{array}{l}\text { (3) student involvement in internship programs } \\
\text { (prosthetics/orthotics facilities) }\end{array}$ & $\begin{array}{l}\text { Documents additional interaction with industrial partners } \\
\text { and preparation of class alumni for careers in } \\
\text { prosthetic/orthotic field, and their understanding of } \\
\text { professional responsibilities. }\end{array}$ \\
\hline $\begin{array}{l}\text { (4) Student research experience (prosthetics, } \\
\text { orthotics research, on- and off-campus) }\end{array}$ & $\begin{array}{l}\text { Documents relevant educational curriculum, student } \\
\text { involvement in life-long learning (outside the classroom), } \\
\text { and understanding of professional responsibilities in } \\
\text { rehabilitation engineering field. }\end{array}$ \\
\hline $\begin{array}{l}\text { (5) Student preparation and matriculation into } \\
\text { post-graduate studies }\end{array}$ & $\begin{array}{l}\text { Documents number of class alumni who pursue certificate } \\
\text { programs in prosthetics, orthotics and rehabilitation } \\
\text { engineering graduate programs. }\end{array}$ \\
\hline $\begin{array}{l}\text { (7) Student surveys (course commentaries, } \\
\text { senior survey, alumni surveys) }\end{array}$ & $\begin{array}{l}\text { Documents student satisfaction with course content, } \\
\text { effectiveness with which course objectives are met, } \\
\text { adequacy of course assessment tools, and student } \\
\text { perceived relationship of course to program educational } \\
\text { objectives and outcomes. }\end{array}$ \\
\hline (9) industry advisory boards & $\begin{array}{l}\text { Reviews course in terms of program breadth, industry } \\
\text { relevance, and student preparation for rehabilitation } \\
\text { careers. }\end{array}$ \\
\hline
\end{tabular}

Extra credit is awarded for timely commentary regarding the guest lectures and field trips as well as recommendations regarding whether or not to include such material in future years. This narrative commentary is summarized and shared with the respective lecturers and "tour guides."

Regardless of the grading format, all students are required to prepare a final report on a topic that is of particular interest to them. To discourage procrastination, sample topics and details regarding the report format are distributed with the class syllabus. Students are required to select their topic and identify several relevant references by midsemester. The early literature search helps students determine the abundance or paucity of resources for their topic. Students must then meet with the instructor to discuss their potential topic and obtain official approval. By spring break, students are required to meet with the instructor a second time and present a tentative outline. The full paper, which is 10 text pages for undergraduates and 15 text pages for graduate students, is then due on the last day of class. The paper is evaluated by the instructor in terms of content (60\%), discussion with respect to class material (20\%), and spelling, grammar, and length (15\%). The remaining $5 \%$ of the project grade is based on the student's preparedness for the preliminary project meetings with the instructor.

IEEE Transactions on Educaton, Vol 45, No. 4 (November 2002): 299-306. DOI. This article is (C) Institute of Electrical and Electronics Engineers (IEEE) and permission has been granted for this version to appear in e-Publications@Marquette. Institute of Electrical and Electronics Engineers (IEEE) does not grant permission for this article to be further copied/distributed or hosted elsewhere without the express permission from Institute of Electrical and Electronics Engineers (IEEE). 
Topics have included prosthetics in Third World countries and prosthetic feetinnovations and testing procedures, spinal orthoses, functional electrical stimulation, and sports programs and training for individuals with disabilities.

For students taking the course for graduate credit, a 15 to 20 -minute oral presentation to the class is required in addition to the extended paper. These oral presentations are evaluated by the instructor in terms of content, organization, visual aids/presentation, and adherence to time constraints. The presentations provide useful public-speaking experience and offer another opportunity for the class to learn about rehabilitation engineering, since many paper topics have not been previously discussed.

\section{SECTION VI.}

\section{Future Modifications}

As always, a course must be modified on a regular basis to stay current and to keep the interest of the students (and faculty). Based on feedback from students, alumni, and industry representatives, potential topics that may be added in the future include functional electrical stimulation (technology, status, and applications), augmentative and alternative communication (assessment, current products, and engineering opportunities), and telemedicine/telerehabilitation (definition, current and future applications, and opportunities for biomedical engineers). Additional or alternative guest lectures may include a physician (physical medicine and rehabilitation as well as vascular surgery) to discuss prosthetic prescription and amputee clinics, pain management for amputees, and/or vascular assessment and surgical techniques; a physical therapist specializing in gait training and rehabilitation for lower extremity amputees; and/or an occupational therapist to discuss training and rehabilitation for upper extremity amputees.

\section{SECTION VII.}

\section{Accreditation Assessment}

The Biomedical Engineering program at Marquette University was recently reviewed under the Accreditation Board of Engineering and Technology criteria (ABET2000). Because much of the accreditation process depends on the educational objectives of the respective program, the educational objectives of our program are summarized as follows: 
1. to provide a foundation in the fundamental concepts and background (mathematics, physical science, life science, engineering, and computing) needed to pursue a successful career in biomedical engineering;

2. to offer students a broad interdisciplinary educational program that combines engineering theory, design, and practice with life science;

3. to prepare graduates with problem identification and solution skills;

4. to prepare graduates who are able to communicate effectively in written, graphical, and oral forms;

5. to provide opportunities for students to develop leadership, team participation, and project management skills;

6. to prepare graduates for biomedical employment or postgraduate training;

7. to foster an appreciation for religious, moral, ethical, and human values;

8. to foster an appreciation for lifelong learning;

9. to maintain a relevant educational curriculum by interacting with industrial partners;

10. to maintain a relevant educational curriculum through health care and research experiences.

With the exception of 1 and 5, this technical elective course addresses all of our educational objectives, as detailed in Table II. In addition, the means by which this course addresses the program outcomes (ABET A-K) are summarized in Table III.

Finally, our department has several tools that provide data with which this course, the curriculum, and program are evaluated. These tools include:

1. student performance (grades and QPA);

2. course portfolios;

3. student involvement in cooperative education and internship programs;

4. student research experience;

5. student preparation and matriculation into postgraduate studies;

6. student involvement in engineering honor societies and organizations;

7. student surveys;

8. employer and employee surveys;

9. industry advisory boards.

The means by which these tools are used to evaluate this course are summarized in Table IV. Overall student performance on the quizzes, exams, and papers indicates that the students are achieving the specific educational objectives of the course. The student surveys indicate that the students value the content of the guest lectures and field trips. As such, this course continues to be offered every spring semester, with the guest lecturers and site visits remaining an integral part of the course. 
NOT THE PUBLISHED VERSION; this is the author's final, peer-reviewed manuscript. The published version may be accessed by following the link in the citation at the bottom of the page.

\section{SECTION VIII.}

\section{Conclusion}

This course has been well received by students. Their comments indicate that they find the clinical applications enlightening and motivational. The inclusion of the clinical professionals emphasizes the interdisciplinary teamwork common in biomedical engineering. In addition to the value these professionals add to the course, this collaboration also results in interdisciplinary design and research projects in rehabilitation engineering.

\section{References}

1J. D. Bronzino, "Chapter 142 - Rehabilitation engineering technologies: Principles of application" in The Biomedical Engineering Handbook, FL, Boca Raton: CRC, pp. 2135-2151, 1995.

2A. Agur, Grant's Atlas of Anatomy, MD, Baltimore:, 1991.

3T. P. Pick, R. Howden, Gray's Anatomy, PA, Philadelphia: Running Press, 1901.

4J. V. Basmajian, C. J. DeLuca, Muscles AliveTheir Functions Revealed by Electromyography, MD, Baltimore:, 1985.

5T. A. McMahon, Muscle Reflexes and Locomotion, NJ, Princeton: Princeton Univ. Press, 1984.

6J. Lieberman, Human Walking, MD, Baltimore:, 1981.

7J. G. Webster, Prevention of Pressure Sores: Engineering and Clinical Aspects, NY, New York: IOP, 1991.

8S. Banerjee, Rehabilitation Management of Amputees, MD, Baltimore:, 1982.

9S. W. Levy, H. Warren, Skin Problems of the Amputee, MO, St. Louis: Green, 1983.

10J. Sabolich, You're Not Alone, OK, Oklahoma City:, 1993.

11L.W. Friedmann, "The epidemiology of amputations" in Physical Medicine and Rehabilitation Clinics of North America Prosthetics, PA, Philadelphia: Saunders, pp. 253-261, 1991.

12G. T. Sanders, B. J. May, R. Hurd, J. Milani, Lower Limb Amputations: A Guide to Rehabilitation, PA, Philadelphia: FA Davis, 1986.

13Northwestern , Lower and Upper-Limb Prosthetics for Physicians and Surgeons, IL, Chicago:, 1992.

14J. H. Bowker, J. W. Michael, Atlas of Limb Prosthetics: Surgical Prosthetic and Rehabilitation Principles, MO, St. Louis: Mosby Year Book, 1992.

15G. Murdoch, R.G. Donovan, "Prosthetic fitting: General concepts" in Amputation Surgery and Lower Limb Prosthetics, MA, Boston: Blackwell Scientific Publications, 1988.

16D. G. Shurr, T. M. Cook, Prosthetics and Orthotics, CT, East Norwalk:, 1990.

17M. Vitali, K. P. Robinson, B. G. Andrews, E. E. Harris, Amputations and Prostheses, U.K., London: Bailliere, 1978.

18A. B. Wilson, Limb Prosthetics, NY, New York: Demos, 1989.

19American Academy of Orthopedic Surgeons, Atlas of Orthotics: Biomechanical Principles and Application, MO, St. Louis: Mosby, 1975.

20 Lower and Upper-Limb Prosthetics and Orthotics, 1992.

IEEE Transactions on Educaton, Vol 45, No. 4 (November 2002): 299-306. DOI. This article is @ Institute of Electrical and Electronics Engineers (IEEE) and permission has been granted for this version to appear in e-Publications@Marquette. Institute of Electrical and Electronics Engineers (IEEE) does not grant permission for this article to be further copied/distributed or hosted elsewhere without the express permission from Institute of Electrical and Electronics Engineers (IEEE). 
NOT THE PUBLISHED VERSION; this is the author's final, peer-reviewed manuscript. The published version may be accessed by following the link in the citation at the bottom of the page.

21W. H. Bunch, R. D. Keagy, Principles of Orthotic Treatment, MO, St. Louis: Mosby, 1976.

22G. Murdoch, The Advance in Orthotics, MD, Baltimore:, 1976.

23D. A. Nawoczenski, M. E. Epler, Orthotics in Functional Rehabilitation of the Lower Limb, PA,

Philadelphia: Saunders, 1997.

24G. K. Rose, Orthotics: Principles and Practice, U.K., London: Heinemann, 1986.

25R. Letts, Principles of Seating the Disabled, FL, Boca Raton: CRC, 1991.

26R. A. Cooper, Wheelchair Selection and Configuration, NY, New York: Demos Medical, 1998.

27R.V. Smith, J.H. Leslie, "Seating and mobility for the severely disabled" in Rehabilitation Engineering, FL, Boca Raton: CRC, pp. 193-251, 1990.

IEEE Transactions on Educaton, Vol 45, No. 4 (November 2002): 299-306. DOI. This article is (C) Institute of Electrical and Electronics Engineers (IEEE) and permission has been granted for this version to appear in e-Publications@Marquette. Institute of Electrical and Electronics Engineers (IEEE) does not grant permission for this article to be further copied/distributed or hosted elsewhere without the express permission from Institute of Electrical and Electronics Engineers (IEEE). 